\title{
Some Polemical Issues in Applied Linguistics
}

\section{Alguns temas polêmicos na disciplina de Linguística Aplicada}

John Robert Schmitz*

UNICAMP

RESUMO: Neste trabalho, examino três temas polêmicos na disciplina de Linguística Aplicada. Argumento, em primeiro lugar, que o desejo de uma definição estável de Linguística Aplicada, de nenhuma forma, tem impedido a pesquisa no âmbito da disciplina. Em segundo lugar, argumento que a "Linguistics Applied" (a linguística do corpus ou a lexicologia) são muito mais abrangentes e sérias do que as práticas "aplicacionistas" (o uso de formalismo, artificialismos e nomenclatura em material didático) que são problemáticos e motivados por interesses comerciais. Em terceiro lugar, argumento que a Linguística Educacional e a Linguística Aplicada têm objetivos de pesquisa que se sobrepóem. No decorrer do trabalho, apresento algumas reservas minhas sobre a Linguística Educacional.

PALAVRAS-CHAVE: Linguistica Aplicada, aplicação da linguística, Linguística Educacional, teoria e prática.

ABSTRACT: In this paper, I look at three polemical issues in Applied Linguistics. I argue, first of all, that the desire for a stable definition of applied linguistics has by no means prevented research in the discipline. Secondly, I contend that the notion or "tradition" of "linguistics applied" (corpus linguistics or lexicography) is broader and more serious than "applicationism" (the use of linguistic formalisms, artificial practices, and terminology) in teaching material that are problematic and motivated by commercial interests. Thirdly, I argue that Educational Linguistics and Applied Linguistics have overlapping research objectives. In the course of the paper, I present some reservations about Educational Linguistics.

KEYWORDS: Applied Linguistics, Linguistics Applied, Educational Linguistics, theory and practice.

\section{Introduction}

My objective here is to examine what I consider to be three controversial issues in the field of Applied Linguistics (henceforth, AL): (i) conflicting definitions of the discipline in the literature, (ii) the relationship between $\mathrm{AL}$

* john.schmitz@uol.com.br 
and Linguistics Applied, (iii) the existence of "educational linguistics" alongside of "applied linguistics". This paper is motivated by my own work in AL over the years and based on my thoughts, and in some cases, on some personal struggles, misgivings as well as a bit of stress with respect to the issues to be examined here. My intention is to encourage dialogue, debate and, no doubt, rebuttal with both colleagues and students of AL.

\section{Conflicting definitions of the discipline}

Some applied linguists, different from specialists in other areas such as psychology, chemistry and law, are unsure of what their discipline entails. Over the course of the years, one observes often conflicting definitions of what the field of AL is. Widdowson (2000a, p.3) a renowned applied linguist states that AL is "conceptually elusive" devoid of a "... stable definition". He argues that there exists a "... persistent and pervasive uncertainty about the nature of the enquiry." Similarly, Hasan and Perrett (1994, p. 222) complain that AL has not found its "center of gravity". James (1993, p. 17) also considers it as "under-defined" with "ragged boundaries" that are "much too wide". These definitions are surprising for a number of reasons. First, Widdowson's plea for stable definition would appear to conflict with the very nature of disciplines for they are situated in time and can change slowly, in some cases, and rapidly, in others. A desire for stable disciplines and neatly delineated boundaries between them suggests an essentialist view of AL, that is, the field is deemed categorically to consist of endeavor $x$, but not endeavor $y$. The wish for a fixed view of AL, I would argue, narrows the field and discourages multi-, inter- and cross-disciplinarity. Schulte and Biguenet (1992, p. 10) warn that members of disciplines "... tend to separate subject matters that by their nature are intricately connected." Such a policy would be a disaster for AL. In this regard, Foucault (1979, p. 218) views academic disciplines as "techniques for ordering of human affairs"; he observes that they tend to exercise surveillance on their membership. Secondly, it would seem to be contradictory to lament that the boundaries of AL are "ragged" and its scope "much too wide" and at the same time consider it to be interdisciplinary or cross-disciplinary where the widening of the boundaries would be the rule. Jacobs and Schumann (1992, p. 282) provide a definition that suggests a markedly different view of AL: 
At present, applied linguistics is perhaps more accurately characterized as the application of various research areas (for example, psychological, sociological, anthropological, neurocognitive) to basic issues in language acquisition, use, analysis, policy, assessment and several other domains.

Students new to AL and perhaps for those students in the Brazilian context who are in the midst of writing up their theses or dissertations for advanced degrees might be perplexed about the uncertainty of what exactly AL entails based on the writings of a number of founding fathers of the field (WIDDOWSON, 2000a; HASAN; PERRET, 1994; JAMES, 1993). But quite surprisingly, a number of younger researchers still harbor doubts about the scope of AL. Edmondson (2005, p. 390) states that he does not "... see how a clear and workable definition of applied linguistics can be agreed on at this point in time”. Lantolf (2006, p. 148) considers the fact that AL “... has expanded its interests beyond language teaching" has contributed to make it difficult "... to figure out what applied linguists is".

Many of these same students in Brazil are, no doubt, quick to observe that a good number of their own instructors hold a different view of AL than some of their colleagues in Europe or the USA. Here is a definition by a Brazilian scholar in AL:

Applied Linguistics, in its present form, is an emergent multidiscipline, or trans-discipline, developed on a multidisciplinary basis of inquiry into language in use, more specifically, into verbal communication within a given social and/or institutional context (SIGNORINI, 2004, p. 74).

Moita Lopes (2006, p. 19) points to a new perspective of AL that “... has contributed to the understanding of AL not as disciplinary knowledge, but as indisciplinary or anti-disciplinary and transgressive one (following PENNYCOOK $^{1}$ (2001 and 2006))".

I would conjecture that these views of AL are consensual in Brazil, for the most part, and most likely few practitioners in the field would want to

${ }^{1}$ Moita Lopes (2006, p. 19), in footnote 3 cites Pennycook. A. Critical Applied Linguistics. New York: Oxford University Press, (2001) and on page 44 in the bibliography, he refers to that publication and also to Pennycook, A. A linguistica aplicada dos anos 90: em defesa de uma abordagem crítica. In: Signorini, I.; Cavalcanti, M. 
return to the consideration of AL as being solely concerned with language teaching methodology. Absent also in Brazilian AL (as far as I can detect) is the view of the discipline held by Brown (1992, p. 144-145) who maintained that it "... must lean on models provided by theoretical disciplines" and is "... essentially exploratory and descriptive... ." In France, AL or "linguistique appliqué" was synonymous with methods of teaching foreign languages (didactique de enseignement des langues, Galisson, 1972). This is no longer the case for the editors of the Revue Française de Linguistique Appliquée (RFLA) inform that the periodical serves as " ... a meeting point for interdisciplinary interaction and confrontation. The RFLA aims to reflect international research in the field of applied linguistics ..." (http:// www. reflajournal.org/presentation.html).

It would be important for students new to the field not to conclude (my emphasis) that views of AL held over 40 years ago were misguided. They served the discipline over the years at a certain point in time but now they have outlived their usefulness. A sense of where the discipline has been and where it is at the present time are essential for a feeling of the history of the discipline that would include knowledge about the contributions of the forerunners and founders of the area in addition to the new voices in LA. The "classics" in the field should be read in addition to the large number of books, important handbooks and seminal articles published in the last twenty years. The canonical texts should not be "revered" but respected.

Even though there are practitioners who agonize over the fact that they cannot find a clear definition of what the field is, I would argue that applied linguists in Brazil and in other parts of the world are not letting the concern about an "adequate" definition deter them from actually getting on with their research in AL. There exist results in the form of reports, theses, books, articles and reviews in scholarly journals pointing to the fact that the researchers are actually contributing to the discipline in its many guises. The many international, national and regional conferences in AL also attest to the productivity of its practitioners. To my mind, there is something wrong about the quest for the definition (my emphasis). It would seem to me that we all know what AL entails (these views are, to be sure, often personal or defined institutionally) and how it can be distinguished from the discipline of linguistics. A paper dealing with second language acquisition would most likely be found in Language, Language Learning or Applied Linguistics. All practitioners in the field of language studies know what type of paper would be accepted by Linguistic Inquiry and what would not be appropriate. It is quite 
clear to most linguists or applied linguists what would be a good contribution for Language Problems and Planning or TESOL Quarterly. The Indian Journal of Applied Linguistics advises prospective contributors in the following terms:

Articles from fields of sociolinguistics, first/ second language acquisition and pedagogy, bilingualism, language planning and others that can be usually covered under applied linguistics are invited. Articles of strictly theoretical linguistic persuasion are outside its scope (Statement of Purpose, Indian Journal of Applied Linguistics, http://www.acquire-content/com/titles/ indian-journal-of-applied-linguistics).

The widening of AL has contributed to making the discipline far more intellectually stimulating and challenging. Its cross-disciplinary stance, critical view and engagement with social issues have linked AL to the social sciences. In fact, for SEALEY and CARTER (2004), AL is a social science (my emphasis). With respect to the area of language teaching which was the initial interest of applied linguists, that very concern has also broadened to include reflective teaching, action-research, empowerment, teacher and student identities, chaos-complexity theory, language awareness among others, not limited to important topics such as classroom methodology or management. De Bot, Verspoor and Lowie (2005, p. 116) are quite pleased with the opening up of AL and not all worried about its being, in their words, "indeterminate in definition". In their words:

The fact that AL as a field is not narrowly focused and constrained has allowed us to explore methods and theories that may have something to say about what language is and how it functions.

In the next part of this paper, I want to look at the notion "linguistics applied" in relation to AL as well as the words "applied", "applying" and "application" that occur frequently in the case of the many other applied disciplines ranging from applied geology to applied sociology.

\section{The relationship between Applied Linguistics and Linguistics Applied}

In the city of Stockholm in 1963, the Council for Cultural CoOperation of the Council of Europe discussed the idea of creating an International Association of Applied Linguistics (AILA). The first meeting of this Association was held in Nancy, France in 1964. Some two hundred 
linguists were invited to present their theories about language in order to ascertain if linguistic theory had any practical applications. In the report published by the Council in 1967, the distinguished linguist Eugeniu Coseriu (1921-2002) ${ }^{2}$ read a paper entitled "Lexical structure and the teaching of vocabulary" that was critiqued by the French linguist Antoine Culioli ${ }^{3}$ who quite bluntly declared that Coseriu's paper had nothing to do with AL! Here are Culioli's words:

The domain of applied linguistics is, quite simply, the application of linguistics to other fields. There is, therefore, a theory and a practice of the application of linguistics to such and such a field, that is to say, in fact, of the articulation of two fields, the one being linguistic, the other being automation, or teaching, or neuropsychology, etc. (p. 62).

Michael Halliday, to be sure, needs no introduction to students and teachers of AL. Not everybody knows that he was also present at the first AILA meeting and expressed the hope that the newly established association would attempt to "... include within its scope the application of linguistics to the teaching of the mother tongue." (p. 179).

One can easily say, in retrospect, that the belief that linguistics can be simply "applied" is naïve; but that was indeed the viewpoint in the mid 60s during the inaugural years of the young discipline. The very question "Does linguistic theory have any applications?" was indeed an appropriate question at that historic period or "situation". Such a question would not be posed at the present time. The report of the linguists ("Linguistic Theories and their Application") who met at the first AILA meeting in Nancy is indeed emblematic for the endeavors called AL as well as "the application of linguistics" were born and came to be known as "linguistics applied". In the

\footnotetext{
${ }^{2}$ Eugeniu Coseriu, born in Romania was an influential linguist who studied in Germany and later on in Uruguay. He authored over fifty books dealing with diachronic and synchronic linguists, linguistic theory. His paper on the lexicon is very informative but his colleague Culioli was correct in stating that his paper had nothing to do with applied linguistics. The problem (was) is that some linguists are involved in the description of linguistic phenomena, but fail to deal with language in real situations and much less in the language classroom.

${ }^{3}$ Antoine Culioli (1924- ) French linguist born in Corsica developed a theory of language known as "La theorie des Operations Enonciatives" (TOE).
} 
mid 70s this notion quickly began to trouble practitioners of the discipline, yet, in spite of the criticisms (WIDDOWSON, 1980, 2000a) there were many instances of "Linguistics Applied" in the course of the years and, for good (or bad?), the notion is still present (as I will indicate shortly).

There are two questions not always asked in discussions about AL and particularly "linguistics applied". The first one is: just what is "applied"? And the second is: precisely what it is applied to?

What is being applied is not always made explicit. In the first place, it could be the grammatical findings of a specific linguistic theory or model; secondly, the complete linguistic model might be appropriated. And thirdly, the psychological underpinnings of a linguistic theory might be used as a framework to how language is acquired. This was attempted by some psycholinguists who used Chomsky's ideas to explain how language was acquired by children. To answer both questions, I present below (FIG. 1) the following diagram:

WHAT is applied

Models of Language Analysis
$\begin{aligned} & \text { traditional grammar } \\ & \text { descriptive (structural) linguistics } \\ & \text { transformational generative grammar } \\ & \text { systemic functional linguistics } \\ & \text { corpus linguistics } \\ & \text { (critical) discourse analysis } \\ & \text { speech acts and pragmatics } \\ & \text { pyscholinguistcs } \\ & \text { sociolinguists }\end{aligned}$

Let us look now at some of the published "applications". The first one is by Quirk, Greenbaum, Leech and Svartik (1972, p. vi) in their monumental grammar of English, A Grammar of Contemporary English point to the underpinnings of their text. Here are the beliefs of the authors in the early $70 \mathrm{~s}$ : 
Each of those [=theories] propounded from the time of Saussure and Jespersen onwards has its undoubted merits, and several (notably the transformational- generative approaches) have contributed very great stimulus to us as to other grammarians.

The work of Quirk et. al is an example of the first type of application, that is, the use of the grammatical findings of transformational theory (dominant at that time, particularly in the USA and other countries); the second type of application is the use of the whole underlying linguistic theory: examples are two textbooks (both designed for native speakers of English), the first entitled English Transformational Grammar and the Teacher of English by Owen Thomas (New York: Holt, Rinehart and Winston, Inc. 1965) and second English Series organized by Paul Roberts (New York: Harcourt, Brace World, Inc., 1964). Another example for English as a second/foreign language is William Rutherford's Modern English (New York, Harcourt Brace Jovanovich, 1968, $2^{\text {nd }}$ ed., 1975). Although Davies (1991, p. 52) quite rightly observes that linguistics applied was more influential in North America and in Continental Europe than in the United Kingdom, Cook, a renowned British applied linguist, in a recent article, (2007) describes his use (back in the 60s of the last century) of phrase structure rules introduced in Chomsky's Syntactic Structures (Janua Linguarum 4, The Hague: Mouton, 1957) in the highly popular textbook Realistic English authored by Abs, B., Cook, V. and Underwood, M. (Oxford, Oxford University Press, [1968], 1978), adopted in many universities and language institutes in Brazil in the 70s and later on.

Celce-Murcia and Larsen-Freeman (1983, p. v) state in their preface to The Grammar Book: An ESL/EL Teacher's Course that linguistics has a great deal to offer teachers of English as a foreign or a second language "... in the way of insights into English grammar". In their text, they inform that they have resorted to transformational-generative grammar to deal with "basic sentence parsing" and the use of "syntactic operations such as the formation of negative sentences and questions". For understanding the function of prepositions and verb tenses, the authors state that they have "drawn insights from traditional grammar and case grammar. To inform learners about the role of the definite and indefinite articles, Celce-Murcia and Larsen-Freeman (1983, ibid) resort to a "discourse perspective". Indeed the authors "applications" are varied and eclectic.

As far as I know, these applications of linguistics were never evaluated critically to ascertain if those students who used the different texts in their university courses actually learned something about language or not. 
With respect to linguistics applied, it is indeed the case that some of the "applications" were simplistic and downright opportunistic (written for the purpose of earning royalties). Textbook exercises that required students to draw "trees", that is, phrase markers (in the technical vocabulary of linguistics) to illustrate the supposed "deep structure" of sentences were far from being pedagogically sound, to put it mildly. A few textbooks for the teaching of Portuguese in Brazilian schools presented linguistic formulas and trees, mere formalisms quite distant from real language input (which is what learners need). Teaching a language is one thing (far more complex than some people believe) and teaching linguistics is indeed quite another matter. Such applications or misapplications are in my view what Moita Lopes (2006, p.18) considers as "applicationalistic". I agree that some of these instances were indeed cases of "misapplied" AL.

But I would not want to go so far as to condemn all "applications" and to discourage those who look to linguistics or to other disciplines as psychology, discourse analysis or education in the attempt to prepare teaching materials. A radical anti-application stance could impede well-intentioned attempts to create and innovate. I find it surprising that Hasan and Perrett (1994, p. 222) criticize AL for taking advantage of "... whatever might be the new bright idea of the decade." In the 60s the audio-lingual approach was in vogue and the use of structural exercises called "pattern drills" were used and, to be sure, in many cases, overused. Widdowson (2000b, p. 27) takes issue with Skehan ${ }^{4}$ (1998, p. 268) who argues that a transformational drill “... does not happen in the real world." Widdowson argues that "... activities such as a transformation drill can be converted by learners into something real and meaningful whereby they exploit the very foreignness of the language..." In this regard, Leffa (2008) takes Wong and Van Patten ${ }^{5}$ (2003) to task for their claim that the pattern drill has no use in the language classroom.

Certainly many teachers exaggerated their use of structural exercises. I agree with Widdowson and Leffa. Anything can be real if the students find it useful. It is no surprise that students, depending on their needs, may find a tourist phrase book, a menu, a map or a railroad timetable to be relevant.

\footnotetext{
${ }^{4}$ The article written by Skehan and cited by Widdowson is: SKEHAN, P. A cognitive approach in language learning. Oxford: Oxford University Press, 1998.

${ }^{5}$ The paper prepared by Wong and VanPattern and cited by Leffa is: WONG, W.; VANPATTEN, B. The evidence is IN: Drills are OUT. Foreign Language Annals. v. 26, n. 3, p 303-423, 2003.
} 
I must confess that in the midst of attempting to prepare teaching materials for different levels of English in schools and in the university, I often felt guilty about looking at the literature on speech acts, on metaphor or on conversation analysis for some insight or inspiration to prepare a handout for my classes. I would argue that "applications" cover a wide variety of endeavors ranging from using the terminology and/or formalisms in the language class (no doubt a misuse) to using data derived from the results of corpus analysis or data from functional linguistics or transformational linguistics. I would not consider corpus linguistics, lexicography or conversation analysis as examples of "applicationalism". To be sure, the three endeavors can be viewed as Linguistics Applied (L-A). One would think that lexicography is entirely dependent on the discipline of linguistics. The structure of dictionary entries may owe little to linguistics, but certainly corpus (my emphasis) linguistics has contributed language data for dictionaries, both bilingual and learner's dictionaries. ${ }^{6}$ Corpus linguistics might owe more to the computer science and the organization of the data by specialists in that area than to specific models of linguistics. Generative-transformational linguistics rejected corpus linguistics but systemic-functional linguistics has been used by some corpus linguists.

It would seem that word "applied" or its cognates "applying" and "application" are in some cases are an embarrassment to AL. It is surprising that while applied linguists hail interdisciplinary and cross-disciplinarity, they, as far as I know, have had little or no contact with other "applied" disciplines such as applied sociology, applied psychology or applied philosophy. It is surprising that applied linguists based on their interdisciplinary or crossdisciplinary orientation have not looked at the "sister" applied disciplines. The discourse of the disciplines is similar to AL. Let us examine three "applied areas":

Applied Anthropology: "Applied anthropology is a complex of related, researchbased, instrumental methods which produce change or stability in specific cultural systems through provision of data, initiation of direct action and/or

\footnotetext{
${ }^{6}$ This field is called "Pedagogical Lexicography" or "Lexicografia Pedagógica", an important sub-discipline of AL. A seminal book in this area for those who read Portuguese is H.A. Welker, Panorama Geral da Lexicografia Pedagógica. Brasília, D.F.: Thesaurus Editora, 2008.
} 
the formation of policy" (van WILLIGEN, J. Applied Anthropology: An Introduction. Boston, Mass., Bergin \& Garvey Publishers, Inc., 1986).

Applied Geography: "The application of geographical knowledge and skills to the solution or resolution of problems within society" (JOHNSON, R.; GREGORY, D.; SMITH, D. (Orgs.) The Dictionary of Human Geography. London: Blackwell References, 1983).

Applied Philosophy: "The International Journal of Applied Philosophy is committed to the view that philosophy can and should be brought to bear upon the practical issues of life." <http://www.pdenet.org/ijaptoc.html>.

Applied Anthropology deals with "research-based instrumental methods", applied geography focuses on the "resolution of problems within society" (similar to LA) and applied philosophy looks at what are considered "practical issues of life". What is interesting about applied philosophy is the issues examined; according to the journal, applied philosophers write about: "... affirmative action, alcohol abuse on college campuses, animal rights, business ethics, gambling, journalism ethics, just-war theory, liberalism, medical ethics, retribution, terrorism, and torture." I am sure that many of topics would be of interest to applied linguists given the cross-disciplinary and transgressive ("indisciplinary") stances in AL (MOITA LOPES, 2006).

One might conjecture that the relationship between anthropology and applied anthropology, between geography and applied as well as between philosophy and applied is different (more integrated?) than that between linguistics and AL. I am not aware, based on my readings, if there exist two traditions in, say, philosophy, on one hand, and "philosophy applied", on the other, as in the case of "A-L" and "L-A". It would be interesting to prepare detailed comparisons or perhaps a taxonomy to confirm or not the assumption that the relation should be something that exists between physics and engineering or between medicine and biology. ${ }^{7}$ It would indeed be instructive but it would take a bit of time to navigate on the internet or to interview specialists in applied fields to discover if there exist separate "applied" departments of philosophy, anthropology or geology.

Not all practitioners in AL were pleased with the notion "applied" but for different reasons. The first journal that bore the name "applied linguistics" for 45 years was Language Learning: A Journal of Applied Linguistics. Beginning

${ }^{7}$ I want to thank a colleague who suggested this to me. 
with volume 43, number 1, the subtitle was changed to: A Journal of Language Studies (henceforth LL). I agree with Alistair Cumming, editor of this journal that the change is not "a radical difference". The first motivation for the change is to recognize the existence of "... the wide range of foundation theories and research methodologies now used to study language issues." The second motivation for the change in subtitle is to

[...] encourage the submission of more manuscripts from (a) diverse disciplines, including applications (my emphasis) of methods and theories from linguistics, psycholinguistics, cognitive science, ethnography, ethnomethodology, sociolinguistics, sociology, semiotics, educational inquiry, and cultural or historical studies to address (b) fundamental issues in language learning, such as bilingualism, language acquisition, second and foreign language education, literacy, culture, cognition, pragmatics and intergroup relations.

To be sure, the disciplines cited in (a) and the issues in (b) are all part and parcel of AL. Davies and Elder $(2004$, p. 4$)$ consider that LL “... seems to have finally accepted the broader church that represents an Applied-Linguistics (A-L) as distinct from a Linguistics- Applied (L-A) approach to language problems.”

Widdowson (2000a) criticizes corpus linguistics, a more encompassing instance of linguistics applied than the appropriation of the results of the grammatical analysis of a particular linguistic theory. He argues that the theories of language and the models of language description that derive from "linguistics applied" are determined by the parent discipline of AL and therefore are "conformist". While he recognizes that corpus linguistics has contributed a great deal to the preparation of learner's dictionaries with computer-based examples, he contends that many of the examples would not be adequate in the language classroom for they would not be "real" or "authentic". For Widdowson, corpus linguistics applied to language teaching and learning is based on "third person data", that is what the computer reveals. This data is not real for the learner for he needs first person data ("when do I use the word?") as well as second person data ("when do you use the word?"). To be sure, Widdowson is rightly concerned with providing instances of real language for the learner. Would it be possible to incorporate in learning materials what is possible (what can/may occur) as well as what is contextually appropriate? In realistic terms, is it possible to include data from all three persons? Certainly all this would be daunting not only for learners but also for those who prepare teaching materials. Indeed Widdowson's reservations 
about corpus linguistics may have to be revised in the course of the coming years. After all, his remarks were published back in the year 2000, almost ten years ago.

In the penultimate sentence of Wissowson's paper (2000a, p. 24), he makes a very important statement that may have been overlooked by some readers. To quote him: "Linguistics applied of the kind of I have criticized in this paper thus poses a challenge to applied linguistics and in the respect is an important influence." I think it would be fair to ask where AL would be today if linguistics applied had not, over the years, challenged AL.

Those colleagues who are fortunate to have access to the excellent Handbook of Applied Linguistics edited by Davies and Elder (2004) have undoubtedly observed that the book is divided into two main sections. The first part, labeled "Linguistics Applied"/ "L-A" consists of six sections with a total of 16 different chapters while the second part contains five sections also with 16 chapters. Certainly it is no simple task to place thirty-two different articles on varied topics into a coherent organizational framework that will please all the many applied linguists who work in its various dimensions. The editors are quite straightforward in declaring that the division into the two traditions, either "L-A" or "A-L" is fraught with difficulties. They recognize the complexity. In their words:

What we have been compelled to realize is that the L-A/A-L distinction is sustainable only at the extremes. Thus the chapters on language attrition or language description may be regarded as largely $\mathrm{L}-\mathrm{A}$, while the concerns of second language learning or of computer assisted language learning are mainly to do with A-L. But in between the distinction is hard to make. It is probably easiest for topics in A$\mathrm{L}$ which deal with issues of language learning and language teaching because they have to do with the "real world", that locution we all refer to when we think of how language is used rather than how it is studied (p. 12).

What this boils down to is the fact that it is often difficult to make a distinction between $\mathrm{AL}$ and its use or application. I agree with Davies and Elder's (ibid, p. 13) position with regard to "L-A" and "A-L":

Is there, then, still a distinction between L-A and A-L? Our answer is that there is but that it cannot easily be found in the topics of interest. Rather, it is found in the orientation of the researchers, and why they are investigating a problem and collecting their data. Do 
they regard themselves as linguists applying linguistics or as applied linguists doing applied linguistics? Are they investigating because they wish to validate a theory? If so, that is L-A. Or is it because they seek a practical answer to a language problem? That is A-L. We do, of course, recognize that in some, perhaps many, cases the researcher will have both interests at heart (p. 13).

In my own reading in the area of language studies, I have come to find it curious that there exists alongside AL another activity called "Educational Linguistics" (henceforth EL). Here is an additional instance in which the word "applied" seems to pose a problem and is duly "erased". Unfortunately I have not found in the specialized literature any discussion of the motivation for the existence of two activities outside of the two proponents of the endeavor. I will examine this in the next section.

\section{Applied linguistics / educational linguistics: two names for the same discipline or competing ones?}

Spolsky's dislike for the word "applied" motivated him to prefer the term "educational linguistics" rather than "applied linguistics". In Spolsky's (1970, p. 145) view, the term "applied linguistics" encompasses too much and does not inform just what linguistics is applied to, and worse still "... it suggests a level of practicality that lacks the dignity of pure linguistics." There are a number of problems with this position. First of all, what is wrong with the possibility of encompassing "too much"? One just has to compare the early AILA meetings with the more recent ones. The number of papers presented in different fields is larger than it was at the first congress in 1964.

To be fair to Spolsky, his remarks were written almost forty years ago and no doubt his views have changed. AL was indeed situated differently in the 70s. Who attributes "dignity" in the academy? Relative status in all endeavors is constructed and subjective. In university contexts, professors of accounting or management may indeed earn a lot more that professors of classical, modern foreign languages as well as linguists, discourse analysts, and applied linguists but none of them have problems with dignity.

In his book Educational Linguistics Spolsky (1978, p. vii) remarks that his dissatisfaction with the term applied linguistics (his emphasis) is due to the “... suggestion linguistics is there just to be applied to any problem”. In his words: 
I prefer a less imperialistic approach, one that suggests that the various fields of linguistics have useful and relevant implications for many practical language related problems.

What is exactly imperialistic in the word "applied"? AL also covers a variety of sub-areas similar to educational linguistics. Spolsky's preference for the term "educational linguistics" can be attested many years after the publication of his Educational Linguistics (1978). In 1991, he published an article "Educational Linguistics" for the International Encyclopedia of Curriculum (LEVY, Arieh (Org.), 1991). While, on one hand, Spolsky cites in his bibliography seminal books and articles authored by "applied linguists", he chooses, on the other hand, not to use it for the title of his text. The motivation for his preference for educational linguistics is, no doubt, his belief that AL has been associated exclusively with pedagogical techniques for teaching foreign language as study skills, use of the overhead projector, preparation of visuals and basic classroom management, important activities indeed, but far removed from research in how learners acquire languages. It is also possible that the existence of some "terminal" graduate courses in AL that entail teacher inservice preparation for American high school teachers who have no intention of becoming researchers has contributed to a search for a new identity. Hence a new name to avoid old associations.

I would, however, contend that his description of what educational linguists do and where they can be found could also define what applied linguists do and where they might work. Spolsky (1990, p. 585) observes:

“...educational linguistics are found and trained in various parts of the university, most often where there is collaboration between scholars in education, linguistics, anthropology, and language departments."

Educational and applied linguists in many cases tend to overlap. In this regard, Crandall (1995, p. 425) quite rightly remarks: "This is an exciting time for applied linguists interested in education" (My emphasis).

In addition to Spolsky, there is another important specialist in the field of language studies who views himself as an educational linguist. Van Lier (1997, p. 95) inserts EL within the "more specific sub-classification of applied linguistics, which in turn he considers "... as a more specific sub-classification of linguistics”. He (1994, p. 201) contends that it is premature to consider educational linguistics as a discipline or field. In his view, to make EL a fullfledged discipline, "political action, lobbying, fund raising and arm twisting" 
will be necessary. The problem here is that if EL is not a field or a discipline, what is it exactly?

Van Lier's remarks reveal a certain tension in the field of language studies. Those who prefer the title "educational linguistics" are concerned with issues of classroom interaction and discourse. They tend to be unhappy with their colleagues who deal with second language acquisition (SLA) for they feel that the acquisitionists fail to deal with the consequences or relevance of acquisition studies for the classroom and teaching.

Van Lier (1997, p.103) also points to problems with both "applied" and "linguistics". In the first place, he states that "applied" might imply that theory building is not a legitimate activity. This appears to be contradictory for Van Lier employs the modal might and goes on to state that the "practice-theory combination" is what AL is all about. There is nothing inherent in the word "applied" that suggests that "theory-building is not a legitimate activity" (p. 103). In this regard, Tomic (1987, p. 93), quite some time ago, argued that “... applied linguistics disciplines are themselves developing theory and thus have a theoretical and a descriptive aspect..."

In the second place, with regard to the term "linguistics", van Lier points to the danger of it being associated with a dominant (hegemonic) model. I do not believe that AL was ever controlled by specific linguistic theory. Widdowson has to be given credit for his efforts to maintain AL independent of subservience to linguistics and its many currents. For van Lier, EL is a subfield of AL which is in turn a sub-field of Linguistics. This entails having a field within a field or a discipline within a discipline. I would view Linguistics as the parent discipline of AL but consider it to be a separate discipline (both academically and institutionally, in some cases) from Linguistics.

With respect to different linguistic models and their relation to $\mathrm{AL}$, Sridhar (1990, p.170) remarks that formal linguistics, specifically generativetranformational theory, excluded the notions of (i) function, (ii) performance, and (iii) context in language analysis. These three aspects of language are pertinent to the goals of AL. It is no wonder then that some applied linguists attached little or no value to linguistic models that excluded real people in real situations. The shift in linguistics from formal autonomous models to socially relevant linguistics, that is, "user-friendly linguistics" (in WEI's terms, 2007, p. 118) has indeed brought AL and Linguistics closer together for many researchers are involved in applied work within AL departments as well as in other departments such as education and communication. 
Van Lier (1994, p. 202) states that researchers in Second Language Acquisition (SLA) have "... distanced themselves from practical educational matters" and as a result have contributed to leaving AL "seriously fractured". I would maintain that SLA researchers have the right to design their own research, but wouldn't it be possible for applied linguists to step in where the acquisitionists have left off and deal with "practical educational matters"? With respect to SLA, I interpret Gass (1993, p. 109) who writes that " $\ldots$ the language classroom needs to be seen as an integral part of the entire research agenda" to mean that she views SLA to be concerned with theory as well as with the practical aspects of acquisition in formal and informal contexts. Her remarks lead me to consider that not all SLA practitioners ignore the sociopolitical consequences of L2 acquisition and bilingual education in the countries where they work. Therefore, I do not view AL as being "fractured" by the disinterest on the part of L2 acquisitionists in the social or political consequences of their work. And there is nothing to impede applied linguists from looking at the political and social and practical implications of L2 acquisition as well as bilingual education. This stance would follow the ideas expressed by the authors in the text edited by Moita Lopes (2006).

In addition, I find it strange that van Lier (1997, p. 103) suggests that the notion "...linguistics" might be too narrow in terms of the diverse knowledge-base and expertise that is required in the applied linguist's job." Once again, van Lier uses the modal might. "Narrow" or "un-friendly linguistics (de BOT, et. al., 2005) is not, for the most part, useful to most applied linguists. Formal linguistic models tend to look inward while sociallyrelevant ones look outside and offer a wide view of language practices (SRIDHAR, 1990).

I do not deny van Lier's right to attempt to establish a field or a discipline or "church" (to use DAVIES; ELDER's, 2004, p. 4 ) term, hopefully without the necessity of "pushing and shoving", as he jokingly states. What troubles me is that his remarks (van LIER, 1997, p. 103) contradict his views about the word "applied" in AL when he concludes that:

I think that it is the applied linguist, who works with language in the real world, who is the most likely to have a realistic picture of what language is, and not the theoretical linguist who sifts through several layers of idealization. 
What is indeed interesting in "educational linguistics" is certainly the term education. But what theories of education would be used? And what would be the role of linguistics with respect to theories of education? It would be remiss to think that AL has not interacted with education. Mcdonough (2002) devotes a number of chapters of his book to encouraging interaction with educational theories and classroom-based methods of research.

The title of this section is in the form of a question: To repeat: are AL and EL the same discipline or competing ones? I would answer that they have the same focus but they are in competition. Competition between both endeavors is felicitous for it can contribute to academic excellence and to a deeper understanding of language and its role in society. One would hope also that both applied and educational linguists will continue to interact with one another. Dialogue between the two areas of interest can encourage collaboration and discourage duplication of effort.

\section{In conclusion}

The frequent statements that AL is a "slippery object" (CAMERON, 2004 , p. 121) attest to a desire for an orderly and essentialist view of the discipline. Definitions should be conceived as "working” ones, for disciplines change their scope over times. Research interests are situated in specific historic moments and different communities of practice in the world have varying conceptions of what their disciplines encompass. I would also contend that the case is similar with respect to other fields of knowledge such as education, linguistics and discourse analysis.

I argue for a distinction between the notion "Linguistics Applied" ("L-A"), on one hand, and examples of "applicationism", on the other. The former, in Davies and Elder's view (2004, p. 11) “[...] looks inward, concerned not to solve language problems "in the real world" but to explicate and test theories about language itself." Examples of "L-A" are all-encompassing and academically serious such as Corpus Linguistics, Language Testing, and Lexicography. "Applicationism" I argue is carried out in classroom situations when teachers prepare teaching materials based on their readings in phonology, discourse analysis or pragmatics. In certain cases, "applicationism" has been infelicitous when, for example, elements of a linguistic theory are presented to learners rather than examples of real language in context. Those endeavors were not pedagogically sound and just developed to make a quick dollar. However, an extreme anti-applicationalist view can inhibit teachers from 
attempting to be original and creative, that is, from "trying things out". I shudder to think what the state of the art in AL, with respect to the teaching of grammar, would be without the work of Quirk et. al. (1972) and that presented by Celse-Murcia; Larsen-Freeman (1983).

While EL may indeed add new insights to our knowledge about the field of education and its relation to language studies, there is a possibility of duplication of research projects, unless there exists a dialogue between the two practices to avoid repetition. While AL has a "janus-like function" (DAVIES; ELDER, op. cit., p. 24) with its two traditions, one "L-A" and the other "AL", EL can only be that and not, I would imagine, *Linguistics educational", but maybe EL could mean linguistics (properly taught, of course!) to educators. Based on my references to the work of van Lier, I conclude that it is in fact another name for Applied Linguistics, as he duly recognizes. There is nothing sacred about names. We could call them both "applied language studies", "language studies" or "theoretical applied language studies" or Applied Linguistics. A rose is a rose but in Turkish it is gül, in Hungarian rózsa, in Japanese bara, in Maltese warda and in Mayan, nikte'. A rose smells just as sweet in all of the languages cited. What is in a name, really? In conclusion, I would say that we all have our preferences (and our prejudices). With respect to naming, I favor the term AL for it has accompanied me for over 50 years. I identify with it and relate to it.

\section{References}

BROWN, G. Very much like a whale: shifting paradigms in applied linguistics. In. PUTZ, M. (Org.). Thirty years of linguistic evolution: studies in honor of René Dirven on the occasion of his sixtieth birthday. Philadelphia: John Benjamins, 1992. CAMERON, L. Review of S. McDonough. Applied Linguistics in language education. System. v. 32, p. 121-122, 2004.

CELSE-MURCIA, M.; LARSEN-FREEMAN, D. The Grammar Book: An ESL/ EFL Teacher's Course. New York: Newbury House/ Harper \& Row, Publishers, Inc., 1983.

COOK, V. Chomsky's Syntactic Structures fifty years on. International Journal of Applied Linguistics. v. 17, n. 1, p. 120-131, 2007.

COUNCIL FOR CULTURAL CO-OPERATION OF THE COUNCIL OF EUROPE. Linguistic theories and their application. Strasbourg: International Association of Publishers of Applied Linguistics (AIDELA), 1967. 
CRANDALL, J. Reinventing (America's) schools: the role of the applied linguist. In: ALATIS, J. E.; Straehle, C. A.; Gallenberger, B.; Ronkin, M. (Org.). Georgetown University Round Table on Languages and Linguistics 1995. Washington, D.C.: Georgetown University Press, 1996.

CUMMING, A. Editor's Statement. Language Learning: A Journal of Research in Language Studies. v. 43, n. 1, p. 1-3, 1993.

DAVIES, A. British applied linguistics: the contribution of S. Pit Corder. In: PHILLIPSON, R.; KELLERMAN, E.; SELINKER, L.; SHARWOODSMITH, M.; SWANN, M. Foreign/Second Language Pedagogy Research. Clevedon: Multilingual Matters, Ltd., 1991.

DAVIES, A.; ELDER, C. The Handbook of Applied Linguistics. (Org.). Malden, Mass.: Blackwell Publishers, 2004.

DE BOT, K.; VERSPOOR, M.; LOWIE, W. Dynamic systems theory and applied linguistics: the ultimate "so what"? International Journal of Applied Linguistics. v. 15, n. 1, p. 116-118, 2005.

EDMONDSON, Willis. Prejudice and practice in applied linguistics. Applied Linguistics. v. 15, n. 3, p. 389-398, 2005.

FOUCAULT, M. Discipline and punish: the birth of the prison. New York:Vintage Books, 1979.

GALISSON, R. Que deviant la linguitique appliqué? Qu'est-ce que la methdologie des langues? Études de Linguistique Appliquée. juillet-septembre, 1972.

GASS, S. Second language acquisition: past, present and future. Second Language Research.v. 9, n. 2, p 99-117, 1993.

HASAN, R.; PERRETT, G. Learning to function with the other tongue: a systematic functional perspective on second language teaching. In: T. ODLIN et. al. Perspectives on pedagogical grammars. Cambridge: Cambridge University Press, 1994.

JACOBS, B.; SCHUMANN, J. Language acquisition and the neurosciences: toward a more integrated perspective. Applied Linguistics. v. 13, n. 3, p. 282-303, 1992.

JAMES, C. What is applied linguistics? International Journal of Applied Linguistics, v. 3, n. 1, p. 17-32, 1993.

LANTOLF, J. Review of Alan Davies and Catherine Elder (Org.). The handbook of applied linguistics. Applied Linguistics. v. 27, n. 1, p. 147-152, 2006.

LEFFA, V. Malhação na sala de aula: o uso do exercício no ensino de línguas. Revista Brasileira de Linguistica Aplicada. v. 8, n. 1, p. 139-159. 
MCDONOUGH, S. Applied linguistics in language education. London: Arnold, 2002.

MOITA LOPES, L. P. (Org.). Por uma Linguística Aplicada Indisciplinar. São Paulo: Parábola, 2006.

PHILLIPSON, R.; KELLERMAN, E.; SELINKER, L.; SHARWOODSMITH, M.; SWANN, M. Foreign/Second Language Pedagogy Research. Clevedon: Multilingual Matters, Ltd., 1991.

QUIRK, R.; GREENBAUM, S.; LEECH, G.; SVARTIK, J. The Grammar of Contemporary English. London: Longman, 1972.

SCHULTE, R.; BIGUENET, J. B. Theories of Translation: an anthology of essays from Dryden to Derrida. Chicago: The University of Chicago Press, 1992.

SEALEY, A; CARTER, B. Applied Linguistics as Social Science. London: Continuum, 2004.

SIGNORINI, I. Applied Linguistics: an Overview. In: STRAZNY, P. (Org.). Encyclopedia of Linguistics. New York: Routledge, 2004.

SPOLSKY, B. Linguistics and Language Pedagogy-Applications or Implications? In: ALLATIS, J. (Org.). Georgetown University Roundtable on Language and Linguistics. Washington, D.C.: Georgetown University Press, 1970.

SPOLSKY, B. Educational Linguistics: An Introduction. Rowley, Mass: Newbury House Publishers, Inc., 1978.

SPOLSKY, B. Educational Linguistics. In: LEVY, A. (Org.). The International Encyclopedia of Curriculum. Oxford: Pergamon Press. 1991.

SRIDHAR, S.N. What are Applied Linguistics? Studies in the Linguistic Sciences. v. 20, n. 2, p. 165-176, 1990.

TOMIĆ, O. M. The integrity of applied linguistics. In: TOMIC,' O. M.; SHUY, R.W. (Org.). The relation of theoretical and applied linguistics. New York: Plenum Press, 1987.

VAN LIER, L. Educational linguistics: field and project. In: ALATIS, J.E. (Org.). Georgetown University Round Table on Languages and Linguistics. Washington, D.C.: Georgetown University Press, 1994.

VAN LIER, L. Apply within, apply without. International Journal of Applied Linguistics. v. 7, n. 1, p. 95-105, 1997.

WEI, L. A user- friendly linguistics. International Journal of Applied Linguistics. v. 17, n.1, p. 117-119, 2007.

WIDDOWSON, H. Models and fictions. Applied Linguistics. v. 1, n. 2, p. 165$170,1980$. 
WIDDOWSON, H. On the Limitations of Applied Linguistics. Applied Linguistics. v. 12, n. 1, p. 3-23, 2000a.

WIDDOWSON, H. Object language and the language subject: on the mediating role of applied linguistics. Annual Review of Applied Linguistics. v. 20, p. 21-33, 2000b.

Recebido em 22/06/09. Aprovado em 02/10/09. 